SHS Web of Conferences 6, 01003 (2014)

DOI: $10.1051 /$ shsconf / 20140601003

(C) Owned by the authors, published by EDP Sciences, 2014

\title{
Research on Rural Economic Ethical Issues in other Countries since Modern Times
}

\author{
Tu Pingrong
}

Research Center of Rural and Social Development, Yichun University, 336000 Yichun Jiangxi, China

\begin{abstract}
The study of the ethical problems of the rural economy abroad has formed a relatively mature theory of genre since modern times, such as Marx and Engels' the moral theory of the peas ant economy; the "self-sufficiency" --smallholder survival moral theory of motivation by Chayanov, Polanyi, Scott; the "rational smallholders"--the profit-motive, economic-and-moral theory by Firth, Tax, Schultz, Popkin; Mendras' economic and moral theory to explain "self-sufficient smallholders" motivation to "rational smallholders" profit motive; the "farmhouse economic ethical thought" by Gandi; Simon's bounded rationality and effectiveness of rational peasant economy ethics, the proposals of the relevant international organizations of the rural economy ethics. Considering the magnitude of related research, it is significant to systematically analyze the theoretical interpretation of these studies, and promote the healthy and orderly development of the rural economy. Furthermore, it is also meaningful to consolidate the theoretical foundation of the rural economy ethics to clarify and ease of ethical confusion in the domestic and international economic and social development in rural areas to promote certain theoretical significance and practical value.
\end{abstract}

Keywords. modern times; abroad; ethics of the rural economy; review

\section{Introduction}

The related foreign researches of rural economy on ethical issues started earlier, which has formed a relatively mature genre theory since modern times. Just as the "Peasant Economy" moral theory of Marx and Engels's; the "Subsistence Peasant" survival motive moral theory of the former Soviet agricultural economist Cai Ya Nuofu, the greatest Germany's economic historian of 20th century Karl Polanyi, the American scholar James Scott, et al; before and after World War II, the neoclassical's "rational peasant" profit motive of economic and moral theory of R. Phils, S. Tucker Adams, Theodore W. Schultz, Popkin et al; in the late 20th century, the economy moral theory transformation form "self-sufficient peasant" survival economic to "rational Peasant" profit motive of famous French sociologist Henri; the "farmhouse economy" Ethics of Mahatma Gandhi, India; the "bounded rationality and effectiveness of the rational" economic ethics of the contemporary American scholar Herbert Simon's; the proposal of ethical issues related to the rural economy of international organizations. Some studies have put into practice in certain fields, which results in a good effect, such as the practice of "Farmhouse Economy", the international FAO meeting documents and initiatives' relevant ethical norms on the agricultural economy are gradually implemented in some countries, and the details are as follows: 


\section{Rural economic ethical issues in other countries since modern times}

\subsection{Marx and Engels' the moral theory of the peasant economy}

The foreign study on the rural economy ethical issues can be traced back to the related discussions on the relationship between Marx and Engels' peasant economy and the ethics. In the text of The Eighteenth Brumaire of Louis Bonaparte, Marx had pointed out a number of peasants under the same living conditions, but without various relationships between them. Their production mode makes them isolated from each other instead of making them mutual exchanges, and such isolated strengthened because of the inconvenient traffic and inaccessibility of France's poor farmers. Almost every farmer is self-sufficient, most of their direct consumer goods are produced by themselves, thus their means of subsistence are mostly exchange with nature, rather than social interaction. ${ }^{[1]}$ Engels thought that "small farmers - large farmers belong to the bourgeoisie - there are different types: some are feudal peasants, they must servitude to their masters; some are tenant, whose rents have increased extremely high, which leads to when they have moderate harvest, farmers can barely maintain himself and his own family life; when they are in a poor harvest, they almost starved to death, unable to pay the rent, which is absolutely dependent on the landowner, and some farmers are operated in their own small plots of land. In most cases, they are relying on secured loans to maintain life, so they just depend on the load usurers like the tenants' rely on landowners. They only have very little income and that income depended on the harvest, which is varied and very unstable." ${ }^{,[2]}$ From the above, the peasants' production activities are isolated, scattered, production tools and techniques of traditional agricultural backwardness, leading to their inefficient agricultural production and severe exploitation. The production of consumer goods is also self-sufficient, under this living environment, small farmers economic activity will inevitably to be conservative, selfish, narrow-minded, undisciplined. Just as Marx pointed out: small farmers scattered and monotonous mode of production and life, is the basis of their ideology and moral values, the farmers work under an isolated state. In this case, it is impossible to develop wealth and reproduction both on the mental condition and the material reproduction. ${ }^{[3]}$ Engels pointed out that, "it is the microeconomics that lead to the demise of farmers. If they want to stick to their individual economy, they are bound to lose houses and homes." ${ }^{[4]}$ Because "the large-scale capitalist economy will crowd out their old mode of production." ${ }^{,[4]}$ In the French and German Farmers, Engels clearly points out that cooperative is the substantial way to small farmers, he said: "We want to save and preserve their property and production, but we can only achieve by turning them into cooperatives possession and production." ${ }^{[4]}$ Which shows that Marx and Engels" "peasant economy" analysis is based on the historical materialism, just as Engels pointed out: "The reason why French farmers are decline is their small piece of land, land dispersed, which was fixed by the ownership form of Napoleon in France"[1]; "the ownership of small piece of land simply can not change the relationship between the farmers and other social class." ${ }^{[1]}$ Engels in the "French and German farmers" also said: "The first great social labor division, which is the separation of urban and rural areas, made the rural people trapped in thousands of years ignorance, the citizens were enslaved their specialized skills. It undermines the basis of rural residents' spiritual development and the basis of urban residents' physical development." ${ }^{,[5]}$ Visibly, Engels emphasized the foundation importance of agriculture, he advocated the elimination of urban and rural differences, and concerned the farmers' interests. That discussion has touched intrinsic ethical issues of agriculture and farmers' regime.

\subsection{The "self-sufficiency"--smallholder survival moral theory of motivation by Chayanov, Polanyi, and Scott}

Chayanov, agricultural economist of former Soviet Union; Karl Polanyi, economic historian of the Austro-Hungarian Empire; James Scott, the American scholar, et al., on behalf of other scholar starting from the sociological perspective, through the empirical research of peasant economy, they found a highly degree self-sufficiency exist, farmers are always seeking to maximize the utility of the 
family, while they seldom considerate the concept of a market economy, such as family income and profits. As Chayanov had done an empirical research on the economic behavior of the Soviet peasant family farms in 1920s, he thought that the peasant economy has its specific meaning, which refers to the "non-capitalist family farms" that family members is the basic unit of farmers" production, and it is different from the capitalist economy, which has its own activity patterns, family labors can not be converted into capital, production activities are not restricted profit principle, it can not calculate profits, the labor and allocation of resources are not obey the principle of maximum economic benefits, but subject to the ethical, moral and traditional customs forces. Chayanov pointed out that the Russian peasant, "the whole year's labor was conducted under the driving of meeting the balance family needs." ${ }^{[6]}$ Their only purpose is to maintain the production of household livelihoods, and production power is the pursuit of maximizing survival. And he also demonstrated the basic principles of farmers economic activities of farmers, the family production and consumption, rural population should be in pace with economic development, the agriculture cooperatives portrait, etc. These theories have a certain degree of rationality, but it ruled out the relations of production factors, completely excluded the market, denied any exchange act, which is not desirable, and it also violate the business ethics moral requirements. Carl. Polanyi, etc., closely followed Chayanov The Early Imperial Trade and Markets(1957), he criticised the view that the capitalist is equivalent to the farmers from another point; he opposed the internationalized of "utilitarian rationalism"; he opposed to look everyone in the world as "utilitarian atom" who pursuits economic rationalization; he promoted the use of "Entity economics" to replace Popkin's "form of economics", pointing out that before the appearing of capitalist market, the economic behavior of small farmers is rooted in the ethical relations, it is carried out for survival purposes; and it expanded mainly move around the market demand and the pursuit of profit after the market appeared. Thus, the study of small farmers' economic activity motivation should be based on the development stage of the social system. James Scott, in "farmer's moral economics: Southeast Asia's rebellion and survival (2004) held that the East Asian identified small community, community (collective) interests above individual rights, in the same community, everyone has a basic morality respect on the basic right of livelihoods. "Little Tradition" under customary law often re-allocation of property in order to protect the rich collective survival, it held that farmers dominant motive are "safety first", "hedging higher than benefits" especially in scarce arable land, barren areas with poor natural conditions, farmers' economic activity is striving for steady and fear of risks, they pursues economic ethics of "survival and safety first".

\subsection{Firth, Schultz, Popkin, Popkin's economy moral theory of rational smallholder's profit motivation}

R. Fales, S. Mr Tusk, Theodore W. Schultz, Popkin of the new classical school before and after the Second World War investigated the farmer's economic behavior from the psychology of the decision, thought that the farmer's economic behavior is rational, their motivation of economic activities is the profit maximization of pursuit. "new classical school" experts in farmers R, fales, S, Mr Tusk and others capitalists " $p$ " theory before world war ii, thought that farmers is calm and rational economic entities under the natural economy, although their "capital" is only a few pennies, but their behavior gives the tendency, rich measurement and logic as businessmen, small entrepreneurs or capitalists. Theodore W. Schultz after the second world war put forward formally the systemic theory of rational peasants in "transforming traditional agriculture" (1999), regarded traditional farmers as "capitalism" enterprise under the condition of a given resources and technology, to pursuit maximum profit, responsive to the price, configuration behaviour of factors of production was in line with the "pareto optimality principle". He pointed out that the internal resource allocation of traditional agriculture is efficient, namely the famous proposition of "poor and efficient" and pointed out the fact that farmers were illiteracy did not prevent their rational activities and motives. The traditional farmers tended to rational pursuit of economic security and stable income in the interests of the choice, often choose utility maximization instead of profit maximization only in bad living environment, production is difficult to self, life is difficult to ensure. In view of this understanding, Schultz pointed out that 
average distribution was prevailing under the condition of planned economy, the broad masses of farmers relied on the collective, worked without the "rational pursuit" and profit motive, the enthusiasm of farmers' labor and the efficiency were low, the development in rural economy must be blocked. The views were got further deepening by Popkin (Samuel. L. Popkin) later, Popkin argues that farmers was as merchants or capitalists, economic behavior behind is also full of profit calculation, pointed out that the farmers is "rational individualist", pointed out that farmers still have a lot of opportunity to rest and will make some risk investment even close to the edge of survival of the poor, the village is the concept of on space, no the identity of the link in interest, the villagers will compete with each other and pursue benefit maximization in "rational peasants" (1979).

\subsection{Mendras" economic and moral theory to explain "self-sufficient smallholders" motivation to "rational smallholders" profit motive}

Mendras, renowned rural sociologists in French analyzed he significance of land for farmers, farmers' way of labor (time and space), the change of the way of knowledge acquisition, the changes of the farmers' consciousness of process, pointed out that "small farmers" formed the small-scale peasant habits in the traditional small peasant economy field, small-scale peasant consciousness, small-scale peasant habits can change after modernization, Farmers attached great importance to the agricultural family management for the profit, broke the equalitarianism idea, small farmers allowed events happen by investing in the rich first, allowed to break the land structure, formed citizens habits to adapt to the modern society, with French countryside modernization as the background in "the end of the farmer". And pointed out that farmers in an unfair position at the same time, because they did not unity, the state took the non-market intervening to agricultural prices, and moral prejudices, these can be seen as farmers and the relationship between state, market and society. The life way of French farmers was gradually moving to cities, social status of farmers was improved through the political participation and career change, rural Renaissance again after they had experienced the changes. Meng Dellas thought that it was a great social revolution from the "small farmers" to the change of "agricultural producers" or "farmers". And pointed out that farmers have reason seems to be an eternal "philosophy", while farmers is the pursuit of the disadvantages in economic activities, but they different from on the basis of the economic rationality of the modern rational, it was not the pursuit of profit maximization in the process of industrialization, urbanization.

\subsection{Simon's bounded rationality and effectiveness of rational peasant economy ethics}

The tenth Nobel Prize winners in economics, contemporary American economist Herbert Simon farmers according to the social reality with the spontaneity, blindness and conservative characteristics of "irrational", put forward theory that man's rationality is limited according to characteristics of "irrational" of farmers in social reality, such as spontaneity, blindness and conservative, and think the rational and irrational of human reason exist at the same time, especially the limitations of information leads to the irrational of making decision and behavior, which targeted in the remote and isolated regions. As companies and small-scale peasant be restricted by their own ability and the various social environment factors, lead to enterprise or small-scale peasant could not in accordance with a sense of rational pattern to develop market economy, the operation process is hard to avoid random, irrationality and even destructive; The utility principle, namely is the implied meaning of the theories of "bounded rationality" lie in giving up using the simple mode of "profit maximization", using "utility" model to analyze the farmers' economic behavior. ${ }^{[7]}$ There is no doubt that these views had certain reference significance for interpretation of contemporary Chinese rural economic ethics problems.

\subsection{The farmhouse economic ethical thought by Gandi}

The "farmhouse economy" ethics thought of Gandhi's start s off from the position of a critical western 
material civilization, regard the realization of the humanitarian moral viewpoint as his pursuit of the rural economy thought, as he said: "although the goal in the modern era is to turn people into machine, my goal is to make the machine-people into people". ${ }^{[8]}$ The emphasis here of Gandhi is people, it is put into the machine returned to endowed with human nature and moral man. In terms of the relations of economic and moral, Gandhi believes that "good economy cannot leave noble morality of person" "[8], so he strongly opposed money worship, and criticized harsh toward the rich conduct for the wicked. He not only regarded the moral as a standard of personal interest and social interest and the spirit regulation means of the people behavior, but also aware of the interactive relationship between economy and moral, noticed the functions of moral value in the field of economy, Gandhi paid the most attention to moral potential role especially in the labor benefits for three factor - the laborer's Professional quality, knowledge and moral potential. He was exposed also to "production factors" embodied the moral and psychological factors, so he think that moral factors were more important than intelligence and physical factors. In terms of work ethics, Gandhi's view was also simple and objective, is an attitude of "the moral consciousness of the masses". Gandhi regard "people engaged in agriculture or other physical labor for making a living" as a principle of economic justice", "living labor" was treated as Gandhi's unique economic moral and ethical principles.[9]In general, Gandhi's "farmhouse economy" ethics thought is based on the original mode of the rural economy in India, proposed all sorts of the idealized moral vision toward the future society, which was in accordance with the lower labor people's will and the moral demands, had its rationality, but unrealistic, in fact, it is hard to work. He Carried out merciless moral criticism to the shortcomings of the western industrial society and the material civilization, which is rationality and forward-looking, but he negate also the efficiency consciousness of modern western industrial civilization, competition concept and other economic ethics thought, which violated the big fear of dialectical materialism and historical materialism, made the blind exclusive mistake.

\subsection{The proposals of the relevant international organizations of the rural economy ethics}

Agricultural ethical problem was regularly come up with in by the United Nations food and agriculture organization's food and agriculture ethics famous expert group officially launched the first meeting On September 26-28th, 2000, and comprehensively stated the basic ethical issues in the field of agriculture, food production and agriculture in ethics, the ethical problems existing in the agricultural development, etc, meeting form a series of related resolutions. Then, the UN's food and agriculture organization in Rome also published "the ethical problems of food and agriculture" and "genetically modified organisms, consumers, food safety and the environment", etc. Series of agricultural ethics file, involved in agriculture agricultural basic ethical issues and ethical commitment, ethics in food and agriculture, to build an ethical and effective and the security of the world's food and agriculture framework and system of the target are discussed in comprehensive and systematic introduced and expounded. Ethical issues of the intensive sustainable agriculture was Published also in 2004, three possible methods: utilitarianism, virtue and the analysis of the rights were put forward on the ethical analysis of agricultural intensification strategy. Fan Dana Mr Shiva of Indian scholar published "the theft of crops in 2006,she thoroughly analyzed problems of agriculture, fisheries, environmental protection, and pointed out various kinds of ethical issues of the international community in the field of agricultural economic exchanges, such as multinational companies have mastered international organizations and international economic order, and the use of transgenic technology and legal to exploit poor farmers in developing countries, the abuse of natural resources in developing countries, destroy the balance of traditional man and nature, to environmental degradation and growing poverty in the developing world to obtain huge profits at the expense, etc.

Above all, the theory of overseas studies on rural economic ethics is relatively mature and the structure is relatively perfect, flexible study methods, especially focus on empirical research, the research object more villages to an individual or a specific area for a long period of time tracking investigation, to avoid the empty grand narrative and talk. The vision of research field is more open, 
small to a certain village ethical case description, big to the moral observation and ethic evaluation of the international community.

But there is also a blocking theoretical logic, the poor academic consensus, no the combination of rural economics and ethics discipline background and knowledge lineage in-depth comprehensive study, especially ethical research exploring agriculture and rural areas of the economy is rarely, some research only can extent from its related field in the speech, can not surround rural economic ethics theory development and practice of the main line system, can not form the academic horizon of the rural economic ethics itself, research and theoretical logic, can't use their own academic language to spread a dialogue with other disciplines and accommodation.

\section{Acknowledgment}

This Articles is supported by social science planning project of Jiangxi province in 2012: Study on problem of contemporary Chinese rural economic ethics (GN: 12zx13); Bidding project from key research bases on humanities and social science of jiangxi province--study center on rural social development from Yichun University: Study on ethical problem of rural social construction (GN: JD1304).

\section{References}

1. Marx and Engels anthology (volume 2) [M]. Beijing: People press, 1995:629

2. Marx. Das kapital (3 volumes) [M]. Beijing: People press, 2004:918

3. Marx and Engels anthology (volume 4) [M]. Beijing: People press, 1995:500

4. Marx and Engels complete works(volume 20)Beijing: People press, 1971:316

5. [Soviet] The Grove. Farmer economic organization[M]. translated by Xiao Zhenghong, tested by Yu donglin, prefaced by Qin Hui, Beijing: central compilation press, 1996:29

6. Zheng Fengtian. System innovation and Chinese peasant economy behavior [M]. Beijing: agricultural science and technology press in China, 2000: 11-12.

7. Peng Shuzhi. Gandhi's rural economy thoughts and moral values [J]. Journal of research in South Asia, 1989(2): 1-14

8. Peng Shuzhi. Modern nationalism movement [M]. Xi' an: northwestern university press, 1987.27

9. Guo yu-hua. reread classic topic on NongMinXue -- "moral economy" or "rational economic" [J]. Journal of reading, 2002(5):104-110 